\title{
A Review on Synthesis of Mullite Ceramics from Industrial Wastes
}

\author{
Thye Foo Choo ${ }^{1,2}$, Mohamad Amran Mohd Salleh ${ }^{1,3, *}$, Kuan Ying Kok ${ }^{2}$ and \\ Khamirul Amin Matori ${ }^{1,4}$ \\ 1 Institute of Advanced Technology, Universiti Putra Malaysia, UPM Serdang 43400, Malaysia; \\ ctfoo@nuclearmalaysia.gov.my (T.F.C.); khamirul@upm.edu.my (K.A.M.) \\ 2 Malaysian Nuclear Agency (Nuclear Malaysia) Bangi, Kajang 43000, Malaysia; \\ kyk1000@nuclearmalaysia.gov.my \\ 3 Department of Chemical and Environmental Engineering, Universiti Putra Malaysia, \\ UPM Serdang 43400, Malaysia \\ 4 Departments of Physic, Faculty of Science, Universiti Putra Malaysia, UPM Serdang 43400, Malaysia \\ * Correspondence: asalleh@upm.edu.my; Tel.: +60-3-894-66286; Fax: +60-3-86567120
}

Received: 25 June 2019; Accepted: 9 September 2019; Published: 11 September 2019

\begin{abstract}
Some industrial wastes are shown to be useful in the production of mullite ceramics. These industrial wastes are rich in certain metal oxides such as silica $\left(\mathrm{SiO}_{2}\right)$ and alumina $\left(\mathrm{Al}_{2} \mathrm{O}_{3}\right)$. This gives wastes the potential to be used as a starting material source for mullite ceramics preparation. The purpose of this review paper is to compile and review various mullite ceramics preparation methods that utilized a variety of industrial wastes as starting materials. This review also describes the sintering temperatures and chemical additives used in the preparation and its effects. A comparison of both mechanical strength and thermal expansion of the reported mullite ceramics prepared from various industrial wastes were also addressed in this work.
\end{abstract}

Keywords: mullite; ceramic; industrial wastes; recycling

\section{Introduction}

Mullite, commonly denoted as $3 \mathrm{Al}_{2} \mathrm{O}_{3} \cdot 2 \mathrm{SiO}_{2}$, is an excellent ceramic material due to its extraordinary physical properties. It has a high melting point, low coefficient of thermal expansion, high strength at high-temperatures, and possesses both thermal shock and creep resistance [1]. These extraordinary thermal and mechanical properties enable the material to be used in applications such as refractories, kiln furniture, substrates for catalytic convertors, furnace tubes, and heat shields.

Mullite can be found only as scarce mineral at Mull Island, Scotland [2]. Due to its rare existence in nature, all the mullite ceramics used in industry are man-made. Much research has been done to prepare mullite ceramics using different precursors, starting either from industrial/laboratory grade chemical [3] or naturally occurring aluminosilicate minerals [4]. However, the cost of these starting materials is expensive, which are synthesized or mined beforehand. For years, researchers have been looking for economical alternatives to synthesize mullite ceramics. Hence, numerous mullite precursors derived from industrial wastes have been reported in the literature [5-41]. These industrial wastes have high content of useful silica and alumina, which are the essential chemical compounds needed to produce mullite ceramics. Other benefits of using these industrial wastes are the energy and cost saving if the wastes were diverted and reutilized as an engineering material. Furthermore, this could also help to reduce the environmental burden and enhance its economic benefit. 


\section{Synthesis of Mullite Ceramics}

\subsection{Starting Materials}

A number of industrial wastes have been used as starting materials to produce mullite ceramics [5-41], as summarized in Table 1. Aluminum sludge has been used as the alumina source in mullite forming mixtures $[5-7,34]$. It was mainly obtained as a byproduct from the aluminum industry, produced by physicochemical treatment of wastewater generated by electrochemical treatment of aluminum surfaces. Aluminum sludge is composed essentially of water $(70-80 \%)$ and aluminum hydroxides, which evolve to $\gamma$-alumina and $\alpha$-alumina, as the temperature increases. In order to compensate for a deficient silica composition as compared to stoichiometric mullite $\left(3 \mathrm{Al}_{2} \mathrm{O}_{3} \cdot 2 \mathrm{SiO}_{2}\right)$, ceramic raw materials [5,6], waste glasses [7], and slate waste [34] was added to the aluminum sludge. The ceramic raw materials that Ribeiro et al. $[5,6]$ used were low-cost common minerals, such as ball clay, kaolin, and diatomite. It should be noted that ball clay and kaolin are minerals that can form mullite by itself via thermal decomposition. The advantages of using aluminum sludge are the small particle sizes and less thermally stable properties of its aluminum hydroxides content, which would readily mix and react with silica source to form mullite upon sintering.

Table 1. Summary of key studies that using different types of industrial wastes to produce mullite.

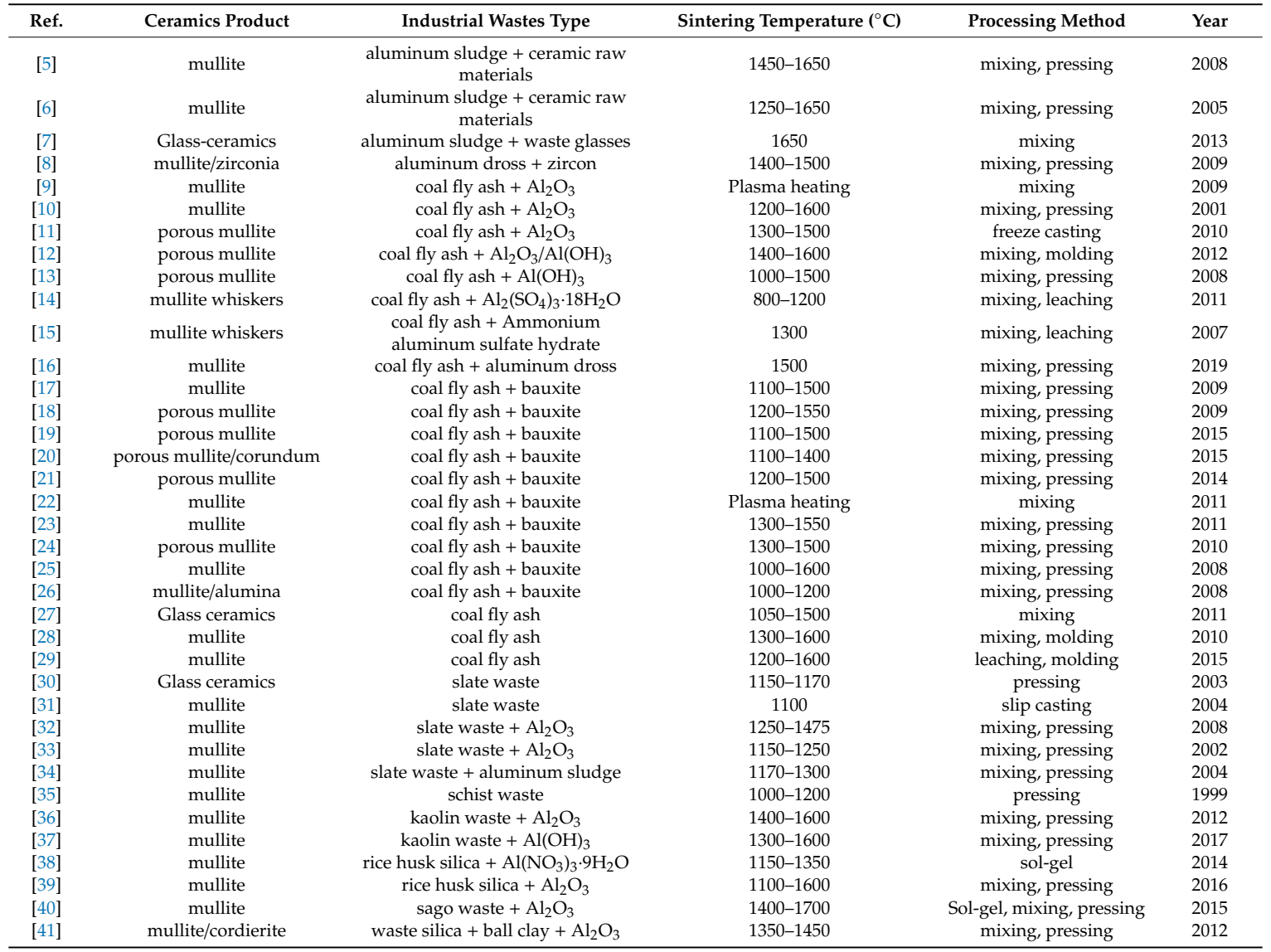

Coal fly ash is an abundant waste product obtained from the combustion of pulverized coal in coal-fired thermal power plants. It consists of fine inorganic particles with main compositions of $\mathrm{Al}_{2} \mathrm{O}_{3}$ and $\mathrm{SiO}_{2}$, which is especially suitable for the fabrication of mullite-based ceramics. Therefore, a large number of studies on coal fly ash as a raw material to produce mullite ceramics have been reported [9-29]. Although mullite is one of the mineralogical components of coal fly ash, the amount of mullite in coal fly ash is rather small. As such to increase the mullite content, aluminum source such as alumina [9-12], aluminum hydroxide [12,13], aluminum sulfate [14,15], aluminum dross [16], 
and bauxite [17-26] was added to the coal fly ash. However, some studies [28,29] showed that it is possible to produce a high crystalline mullite ceramic with no extra aluminum sources. Results from Guo et al. [28] indicated that the desilication-fly ash was more suitable to be used to prepare the mullite ceramics than fly ash. Lin et al. [29] prepared high-performance mullite ceramics from fly ash of high $\mathrm{Al}$ content; the original fly ash was pretreated with alkali and acid to adjust the chemical composition. Their beneficiated sintering sample exhibited a mullite content of $88.33 \%$.

Studies also show that coal fly ash is suitable for the fabrication of porous mullite membranes [11-13,18-21,24]. For example, Yang et al. [11] reported that highly porous mullite ceramic with apparent porosity of $67 \%$ and a unique pore structure can be prepared by controlled freeze casting of tertiary-butyl alcohol/coal fly ash slurry with an appropriate addition of $\mathrm{Al}_{2} \mathrm{O}_{3}$. Li et al. [12] were able to produce porous mullite ceramics with a bending strength about $100 \mathrm{MPa}$ and apparent porosity about $55 \%$ by starch consolidation method using fly ash at $1550{ }^{\circ} \mathrm{C}$. Dong et al. [13] used a heterogeneous-precipitation method to produce porous mullite ceramics with fly ash and aluminum hydroxide as starting materials. Besides the above-mentioned techniques, traditional route that involve mixing, pressing, and reaction sintering of mullite precursor is the most commonly used technique. For instance, porous mullite ceramic membrane supports were prepared by Dong et al. [18], who directly used the mixture of fly ash and bauxite via the reaction sintering technique. Zhu et al. $[19,20]$ prepared ceramic membrane support with the same starting materials, but with additional $\mathrm{AlF}_{3}$ and $\mathrm{MoO}_{3}$. This resulted a membrane support with high open porosity and high permeances for both gas and water without strength degradation. Cao et al. [21] and Dong et al. [24] also used coal fly ash and bauxite to produce porous mullite ceramic membrane supports with the use of different additives such as the combination of $\mathrm{AlF}_{3}, \mathrm{~V}_{2} \mathrm{O}_{5}$, and pure titania.

Various aspect ratios of mullite crystals could be produced using coal fly ash. For example, Tan [14] reported synthesis of long acicular mullite crystals by firing appropriate mixtures of coal fly ash and aluminum sulfate in sodium sulfate flux at $100{ }^{\circ} \mathrm{C}$ for $3 \mathrm{~h}$. The crystals produced exhibited a diameter of $0.06-0.3 \mu \mathrm{m}$ with an aspect ratio of $>25$ (Figure 1a). Orthorhombic acicular mullite crystals with a diameter of $0.6-1.8 \mu \mathrm{m}$ with an aspect ratio $>30$ (Figure $1 \mathrm{~b}$ ) have been prepared by firing compacts of coal fly ash and $\mathrm{NH}_{4} \mathrm{Al}\left(\mathrm{SO}_{4}\right)_{2} \cdot 12 \mathrm{H}_{2} \mathrm{O}$ powders, with a small addition of $\mathrm{NaH}_{2} \mathrm{PO}_{4} \cdot 2 \mathrm{H}_{2} \mathrm{O}$,

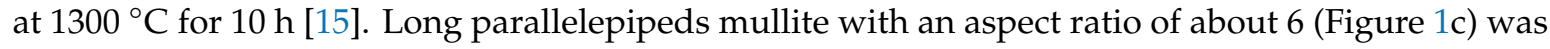
prepared using high-aluminum fly ash and bauxite as raw materials [17]. Homogeneous equiaxial grains (aspect ratio of 1 ) of mullite (Figure 1d) was prepared by firing a mixture of $50 \%$ coal fly ash and 50\% bauxite with transferred arc plasma torch at $10 \mathrm{~kW}$ input power level for $3 \mathrm{~min}$ [22].

Slate wastes are residues that have resulted from cutting and polishing operations in the slate quarries. The wastes composed basically of crushed slate rock, water, and lubricants, in mud form. Slate is a metamorphic stone resulting from fine sediment deposits that are exposed to high-temperatures and pressures. The typical chemical composition of the slate powder mostly consists of $\mathrm{SiO}_{2}$ and $\mathrm{Al}_{2} \mathrm{O}_{3}$, as well as other oxides including $\mathrm{FeO}, \mathrm{Fe}_{2} \mathrm{O}_{3}, \mathrm{TiO}_{2}, \mathrm{MnO}, \mathrm{MgO}, \mathrm{CaO}, \mathrm{Na}_{2} \mathrm{O}, \mathrm{K}_{2} \mathrm{O}$, and $\mathrm{P}_{2} \mathrm{O}_{5}$. The use of slate wastes as raw materials in the manufacturing of mullite ceramics is considered a good option because of the high content of useful silica or alumina in the slate. The slate powder characterization of Souza et al. [31] showed that the quartz phase concentration was high and would be adequate to produce ceramic pieces. Catarino et al. [30] used slate wastes to produce tiles. Their samples were uniaxially pressed at $40 \mathrm{MPa}$ and subsequently sintered at temperatures close to $1150^{\circ} \mathrm{C}$. The qualitative XRD measurement estimated the amounts of glassy phase and mullite to be $56 \%$ and $20 \%$ respectively. A study by Oliveira et al. [32] verified that mullite with a composition close to $\mathrm{Al}_{4} \mathrm{SiO}_{8}$ (mullite 2:1), can be prepared by reaction sintering of slate and alumina fine waste powders, and the optimum sintering temperatures were found to fall in the range of $1425-1450{ }^{\circ} \mathrm{C}$. Martins et al. [33] reported that $\gamma$-alumina that was added to the slate powders enhances the amount of mullite formed and inhibits the formation of pores and swelling of the specimens when sintered at temperatures above $1150{ }^{\circ} \mathrm{C}$. As a continuation of their previous work, Martins et al. [34] studied the effect of mixing aluminum 
hydroxide sludge with slate wastes, the study shows that there is a significant increase of secondary mullite phase in the 2:1 mixture (alumina/silica ratio) after sintering at $1270{ }^{\circ} \mathrm{C}$.

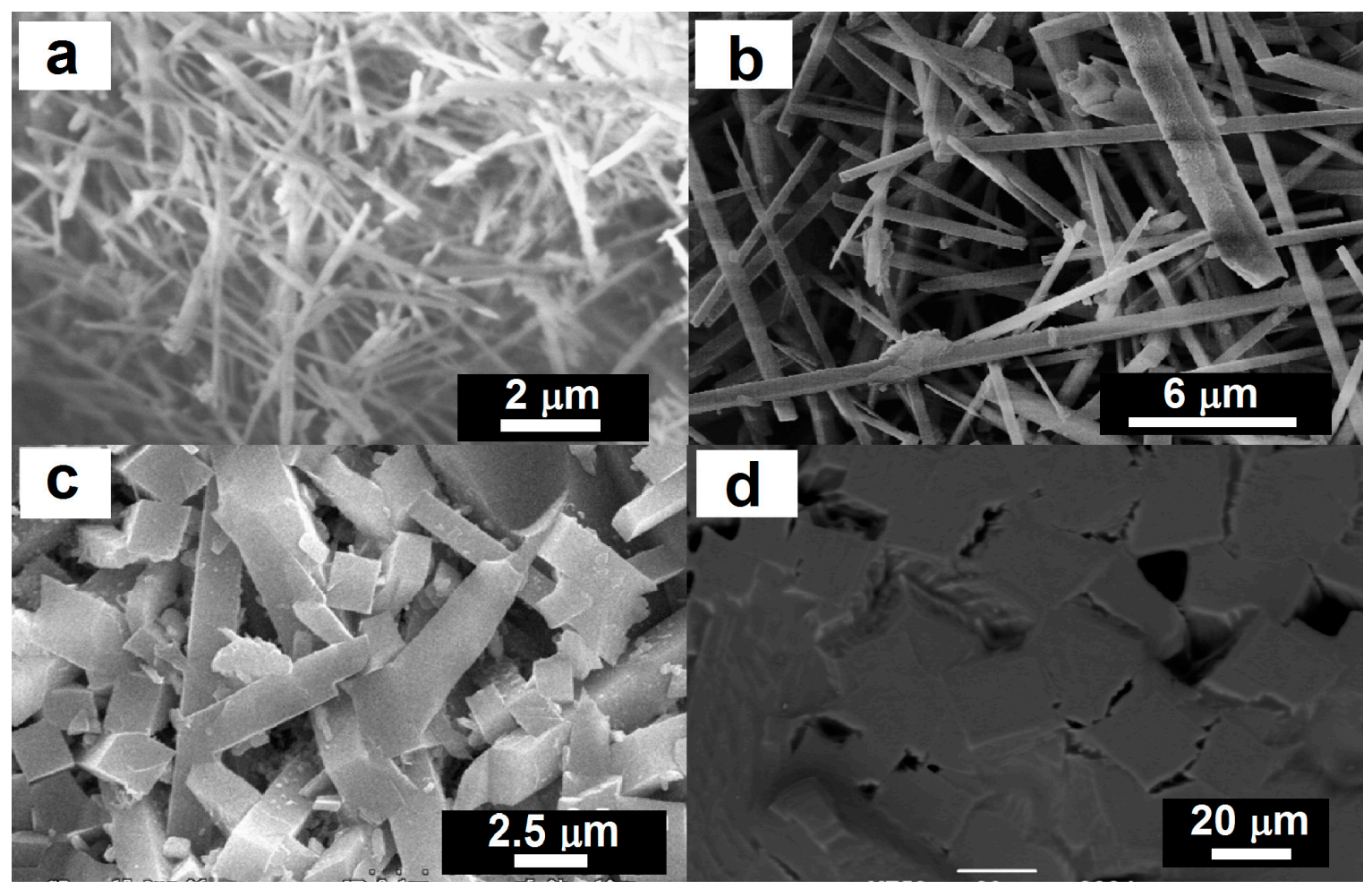

Figure 1. SEM microphotographs of various aspect ratios of mullite crystals produced using coal fly ash (a) Aspect ratio of $>25$. Reprinted with permission from [14] (Copyright (2011) Elsevier). (b) Aspect ratio of $>30$. Reprinted with permission from [15] (Copyright (2007) Elsevier). (c) Aspect ratio of 6 . Reprinted with permission from [17] (Copyright (2009) Elsevier). (d) Aspect ratio of 1. Reprinted with permission from [22] (Copyright (2011) Elsevier).

Besides the above-mentioned wastes, a few other wastes have also been investigated, such as schist waste [35], Kaolin waste [36,37], rice husk silica [38,39], sago waste [40], and silica fume waste [41]. Schist is a medium grade metamorphic rock which is often used as tiles for flooring. From schist mining to the last machining process, thousands of tons of wastes has been generated. Recovery of these wastes is critical. Vieira et al. [35] successfully sintered schist waste to produce a mullite composite with excellent mechanical properties. Similar to schist waste, thousands of tons of kaolin waste are also produced each day in mining and mineral beneficiation. In the study of kaolin waste utilization, Brasileiro et al. [36] reported that the formation of secondary mullite with improved properties can be obtained from microwave sintering kaolin waste in mixtures with alumina. The utilization of agricultural wastes such as rice husk silica and sago waste as mullite precursor were found to be feasible too. Sembiring et al. [38] demonstrated that mullite precursor derived from rice husk silica and aluminum nitrate hydrate is a potential alternative raw material for the production of mullite ceramic. Sago waste is a byproduct from the sago palm (Metroxylon sagu) processing industry. A study by Aripin et al. [40] showed that a highly developed mullite structure could be produced from $\alpha-\mathrm{Al}_{2} \mathrm{O}_{3}$ and silica xerogel that were converted from sago waste ash and the crystalline mullite could be formed at a temperature as low as $1100{ }^{\circ} \mathrm{C}$ and a concentration of $\alpha-\mathrm{Al}_{2} \mathrm{O}_{3}$ as low as $20 \mathrm{~mol} \%$. Elsewhere, Khattab et al. [41] studied the feasibility of using silica fume as a source of silica in the presence of calcined ball clay, $\mathrm{MgO}$, and calcined alumina to fabricate cordierite-mullite composites. His study showed that the optimum temperature for the formation of cordierite-mullite composites was achieved at $1400{ }^{\circ} \mathrm{C}$. 


\subsection{Sintering Temperature}

In general, mullite formation started at a lower temperature around $1000{ }^{\circ} \mathrm{C}$ and the amount of mullite increased at subsequent increase in temperature. For instance, Suriyanarayanan et al. [9] showed that mullitization occurred at $920^{\circ} \mathrm{C}$. Martins et al. [34] reported that an increase of mullite content started from $980^{\circ} \mathrm{C}$ and there is an increase of secondary mullite phase in the resultant material up to sintering temperatures of $1300{ }^{\circ} \mathrm{C}$. Sembiring et al. [38] reported that mullite formation started at $1150{ }^{\circ} \mathrm{C}$ and its abundance increased drastically with an increase in temperature from 1150 to $1350{ }^{\circ} \mathrm{C}$, resulting in an increased mullite phase content from 30.9 to $67.7 \mathrm{wt} \%$. A similar finding was reported by Francis et al. [7], where mullite which is transformed from Al-Si-oxides wastes produced an exothermic peak in the temperature range of $878-973^{\circ} \mathrm{C}$. While Ribeiro [5] reported that mullite was already observed at temperatures lower than $1350^{\circ} \mathrm{C}$, but the presence of some precursor phases, such as quartz and alumina, were still visible. However, subsequent sintering at the temperature of $1650{ }^{\circ} \mathrm{C}$ showed that mullite is the single crystalline phase formed. Besides the increase in the mullite content, high-temperature sintering has a densification effect on the ceramic. As Dong et al. [25] reported that above $1450{ }^{\circ} \mathrm{C}$, the relative density increased sharply with an increase in firing temperature. Their sample sintered at $1600^{\circ} \mathrm{C}$ for $4 \mathrm{~h}$ had a relative density of $93.94 \%$.

To achieve higher mullite content and density, it is desirable to use as high a sintering temperature as possible, due to the higher reaction rate between $\mathrm{Al}_{2} \mathrm{O}_{3}$ and $\mathrm{SiO}_{2}$ in the precursor. However, excessive silica content in the precursor could lead to a sample deformation or meltdown in high-temperature sintering. Kusnierova et al. [27] reported that in a preparation of mullite ceramic using high silica content coal fly ash $\left(\mathrm{Al}_{2} \mathrm{O}_{3} / \mathrm{SiO}_{2}\right.$ weight ratio of 0.4$)$, the process of mullitization stopped and the whole volume of the sample were melted at $1500^{\circ} \mathrm{C}$. Choo et al. [16] also reported that samples with high silica content $\left(\mathrm{Al}_{2} \mathrm{O}_{3} / \mathrm{SiO}_{2}\right.$ weight ratio less than 1.5) were deformed and melted at $1500{ }^{\circ} \mathrm{C}$.

\subsection{Sintering Aids-Additives}

Table 2 lists the chemical additives used in the preparation processes of mullite and its effects reported in the literature. Low-temperature sintering using sintering aids is a relatively important method to reduce the production cost of mullite ceramics. Research has been carried out to lower sintering temperature for obtaining mullite ceramics via the liquid-phase process with different sintering aids. $\mathrm{CaF}_{2}, \mathrm{H}_{3} \mathrm{BO}_{3}$ [7], $\mathrm{Na}_{2} \mathrm{SO}_{4}$ [14], $\mathrm{TiO}_{2}$ [24], $\mathrm{AlF}_{3}$, and $\mathrm{MoO}_{3}$ [12,19] have been reported as effective aids to lower sintering temperature. For instance, $\mathrm{Zhu}$ et al. [19] reported that with $\mathrm{AlF}_{3}$ and $\mathrm{MoO}_{3}$ addition to coal fly ash-bauxite mixtures, the temperature at which mullite phase was formed, is lowered by $150{ }^{\circ} \mathrm{C}$, as compared with the samples prepared without any additives. Dong et al. [24] also demonstrated the possibility of using $\mathrm{TiO}_{2}$ as sintering aids. The sintering activity of fly ash based mullite was inhibited by $\mathrm{TiO}_{2}$ at low-temperatures, but at high-temperatures, the secondary mullitization reaction temperature was effectively lowered. These sintering aids assist the formation of low melting point liquids during firing and enhance the volume fraction of the glassy phase present, thus facilitating the growth of mullite crystals. One important fact to be noted is that impurities and oxide components in the industrial wastes can contribute to the formation of low melting point liquids with a relatively low viscosity in the $\mathrm{Al}_{2} \mathrm{O}_{3}-\mathrm{SiO}_{2}$ system [11], which also facilitates mullite crystals growth process in a similar way.

Chemical additives can also be used to promote densification for mullite ceramics. Li et al. [17] synthesized mullite ceramics from high-aluminum fly ash and bauxite with $\mathrm{V}_{2} \mathrm{O}_{5}$ addition. They have shown that the apparent porosity and water absorption decreased with an increase in the $\mathrm{V}_{2} \mathrm{O}_{5}$ content at $1500{ }^{\circ} \mathrm{C}$. Yang et al. [11] synthesized porous mullite from coal fly ash and $\mathrm{Al}_{2} \mathrm{O}_{3}$, and the additions of $10 \mathrm{wt} \% \mathrm{Y}_{2} \mathrm{O}_{3}$-doped $\mathrm{ZrO}_{2}$ also decreased the porosity and average pore size of mullite. In the research conducted by Jung et al. [10], the addition of 3Y-PSZ powders was found to inhibit grain growth of the mullite and enhanced the densification process. 
Table 2. Example of chemical additives used in the preparation processes of mullite in the literatures.

\begin{tabular}{|c|c|c|c|c|}
\hline Ref. & Ceramics Product & Industrial Wastes Type & Additives & Effects \\
\hline $\begin{array}{c}{[7]} \\
{[10]}\end{array}$ & $\begin{array}{l}\text { Glass ceramics } \\
\text { mullite }\end{array}$ & $\begin{array}{l}\text { Aluminum sludge }+ \text { waste glasses } \\
\text { coal fly ash }+\mathrm{Al}_{2} \mathrm{O}_{3}\end{array}$ & $\begin{array}{c}\mathrm{CaF}_{2}, \mathrm{H}_{3} \mathrm{BO}_{3} \\
\text { 3Y-PSZ }\end{array}$ & $\begin{array}{l}\text { reduced sintering temperature } \\
\text { increased densification }\end{array}$ \\
\hline [11] & porous mullite & Coal fly ash $+\mathrm{Al}_{2} \mathrm{O}_{3}$ & $\begin{array}{c}\text { Y2O3-doped } \mathrm{ZrO} 2 \\
\text { (3YZ) }\end{array}$ & increased densification \\
\hline [12] & porous mullite & Coal fly ash $+\mathrm{Al}_{2} \mathrm{O}_{3} / \mathrm{Al}(\mathrm{OH})_{3}$ & $\mathrm{AlF}_{3}$ & assisted anisotropic mullite growth \\
\hline [14] & mullite whiskers & Coal fly ash + aluminum sulfate anhydrous & $\mathrm{Na}_{2} \mathrm{SO}_{4}$ & $\begin{array}{l}\text { reduced sintering temperature, } \\
\text { assisted anisotropic mullite growth }\end{array}$ \\
\hline [15] & mullite whiskers & Coal fly ash + Ammonium aluminum sulfate hydrate & $\mathrm{NaH}_{2} \mathrm{PO}_{4} \cdot 2 \mathrm{H}_{2} \mathrm{O}$ & assisted anisotropic mullite growth \\
\hline [20] & porous mullite & Coal fly ash + bauxite & $\mathrm{AlF}_{3}, \mathrm{MoO}_{3}$ & reduced sintering temperature \\
\hline [21] & porous mullite & Coal fly ash + bauxite & $\mathrm{AlF}_{3}, \mathrm{~V}_{2} \mathrm{O}_{5}$ & assisted anisotropic mullite growth \\
\hline [23] & mullite & Coal fly ash + bauxite & $\mathrm{MgO}$ & assisted anisotropic mullite growth \\
\hline [24] & porous mullite & Coal fly ash + bauxite & $\mathrm{TiO}_{2}$ & reduced sintering temperature \\
\hline
\end{tabular}

It has been well documented that mullite whiskers are very effective in toughening and strengthening ceramics. These needle-like mullite whiskers constructed a large compact interlocking structure, which enhanced the physical strength and toughness of the mullite ceramics effectively. Doping with chemical additives such as $\mathrm{AlF}_{3}$ [12], $\mathrm{Na}_{2} \mathrm{SO}_{4}$ [14], $\mathrm{NaH}_{2} \mathrm{PO}_{4} \cdot 2 \mathrm{H}_{2} \mathrm{O}$ [15], $\mathrm{V}_{2} \mathrm{O}_{5}[17,21]$, and $\mathrm{MgO}$ [23] assisted anisotropic growth of these mullite whiskers. For example, Park et al. [15] has produced mullite whiskers with a diameter of 0.6-1.8 $\mu \mathrm{m}$ and aspect ratio larger than 30 by firing compacts of coal fly ash and $\mathrm{NH}_{4} \mathrm{Al}\left(\mathrm{SO}_{4}\right)_{2}$ powders with addition of $2 \mathrm{wt} \%$ of $\mathrm{NaH}_{2} \mathrm{PO}_{4} \cdot 2 \mathrm{H}_{2} \mathrm{O}$, at $1300{ }^{\circ} \mathrm{C}$ for $10 \mathrm{~h}$.

\section{Mechanical Strength}

Table 3 lists the mechanical strengths of mullite ceramic products sintered at different temperatures that were reported in various literatures. The mullite ceramic products were categorized as mullite (polycrystalline mullite ceramic with little or no amorphous glass phase), mullite-containing glass-ceramic (mullite crystals embedded in amorphous glass matrix, e.g., porcelain-like materials) and mullite-containing ceramic composites (e.g., mullite/corundum composite and mullite/cordierite composite). The mullite and mullite-containing glass-ceramics reviewed in this report contained various content of silica amorphous phase. Some mullite ceramics are highly crystalline with small amount of amorphous phase [25], while some mullite-containing glass ceramics are highly amorphous [30,35]. The mechanical strengths of the mullite ceramic were shown to be dependent on the relative volume of crystalline and amorphous phases. The results reported in [30,35] showed that mullite-containing glass ceramics exhibited high flexural strength even though it was sintered at a relatively low-temperature. This is due to the amorphous glass phase which served as a binder lodging into the pores between the mullite crystallites and was thus responsible for the increase in the mechanical strength of the samples [35]. However, for these mullite-containing glass ceramics, the degradation of the mechanical strength starts at a much lower sintering temperature. As reported by Vieira et al. [35], the flexural strength of the mullite-based glass started to drop at the sintering temperature of $1200^{\circ} \mathrm{C}$, concluding that it was related to an excess of amorphous silica formation at high-temperature sintering. The excess of this amorphous fragile phase in ceramic could be responsible for the decrease of mechanical strength. The mechanical strengths of the mullite ceramic were also dependent on crystalline phase composition. Khattab et al. [41] reported that the compressive strength increased with an increase in the cordierite content, until a maximum value was achieved for $80 \mathrm{wt} \%$ of cordierite content. This was ascribed to the decrease in porosity that resulted in higher densification.

It also can be seen that the mechanical strength of the mullite ceramic increases with an increasing sintering temperature. Porosity was reduced by the increase of sintering temperature and thus improved the mechanical strength of the ceramic. The porosity of the sample influences mechanical strength inversely, as shown in Figure 2. The improvement of flexural strength $[19-21,25,28,34]$ and compressive strength [29] is ascribed not only to the enhanced densification but also to the reinforcement generated by the large network structure of compact interlocked acicular mullite crystals embedded 
in the glassy phase. The increase in sintering temperature also resulted in the precipitation of more mullite coarse crystals [25].

Table 3. The mechanical strengths of different mullites reported in various references.

\begin{tabular}{|c|c|c|c|c|c|c|}
\hline Ref. & Ceramics Product & Sintering Temp. $\left({ }^{\circ} \mathrm{C}\right)$ & $\begin{array}{l}\text { Compressive } \\
\text { Strength (MPa) }\end{array}$ & $\begin{array}{c}\text { Flexural } \\
\text { Strength(MPa)/Type }\end{array}$ & $\begin{array}{c}\text { Fracture Strength } \\
\text { (MPa) }\end{array}$ & Porosity (\%) \\
\hline [17] & mullite & 1500 & - & 108/3-point & - & 1.42 \\
\hline \multirow[t]{3}{*}{ [25] } & Mullite & 1500 & - & 104/3-point & - & 26 \\
\hline & & 1600 & - & 186/3-point & - & 6 \\
\hline & & 1300 & - & 34/3-point & - & 39.6 \\
\hline [28] & Mullite & 1400 & - & 45/3-point & - & 32.7 \\
\hline \multirow[t]{2}{*}{ [29] } & Mullite & 1500 & 104 & - & - & 13 \\
\hline & & 1600 & 169 & - & - & 1 \\
\hline [33] & mullite & 1250 & - & 43/3-point & - & - \\
\hline [11] & mullite & 1500 & 23.2 & - & - & 66.9 \\
\hline \multirow[t]{2}{*}{ [12] } & mullite & 1600 & - & 75/3-point & - & 45 \\
\hline & & 1450 & - & 45/3-point & - & 44 \\
\hline [18] & Mullite & 1500 & - & 52/3-point & & 43 \\
\hline [30] & $\begin{array}{l}\text { mullite-containing } \\
\text { glass ceramics }\end{array}$ & 1170 & - & 92/3-point & - & - \\
\hline \multirow{4}{*}{ [35] } & & 1100 & - & 45/3-point & - & - \\
\hline & mullite-containing & 1170 & - & 95/3-point & - & - \\
\hline & & 1200 & - & 80/3-point & - & - \\
\hline & & 1200 & - & 80/Biaxial & - & 48 \\
\hline \multirow{3}{*}{ [19] } & mullite/corundum & 1300 & - & 105/Biaxial & - & 46 \\
\hline & composite & 1400 & - & 145/Biaxial & - & 42 \\
\hline & & 1500 & - & 158/Biaxial & - & 30 \\
\hline \multirow{3}{*}{ [20] } & mullite/corundum & 1200 & - & 61/3-point & - & - \\
\hline & composite & 1300 & - & 68/3-point & - & - \\
\hline & & 1200 & - & 48/Biaxial & - & 33 \\
\hline [21] & mullite/corundum & 1300 & - & 65/Biaxial & - & 38 \\
\hline
\end{tabular}

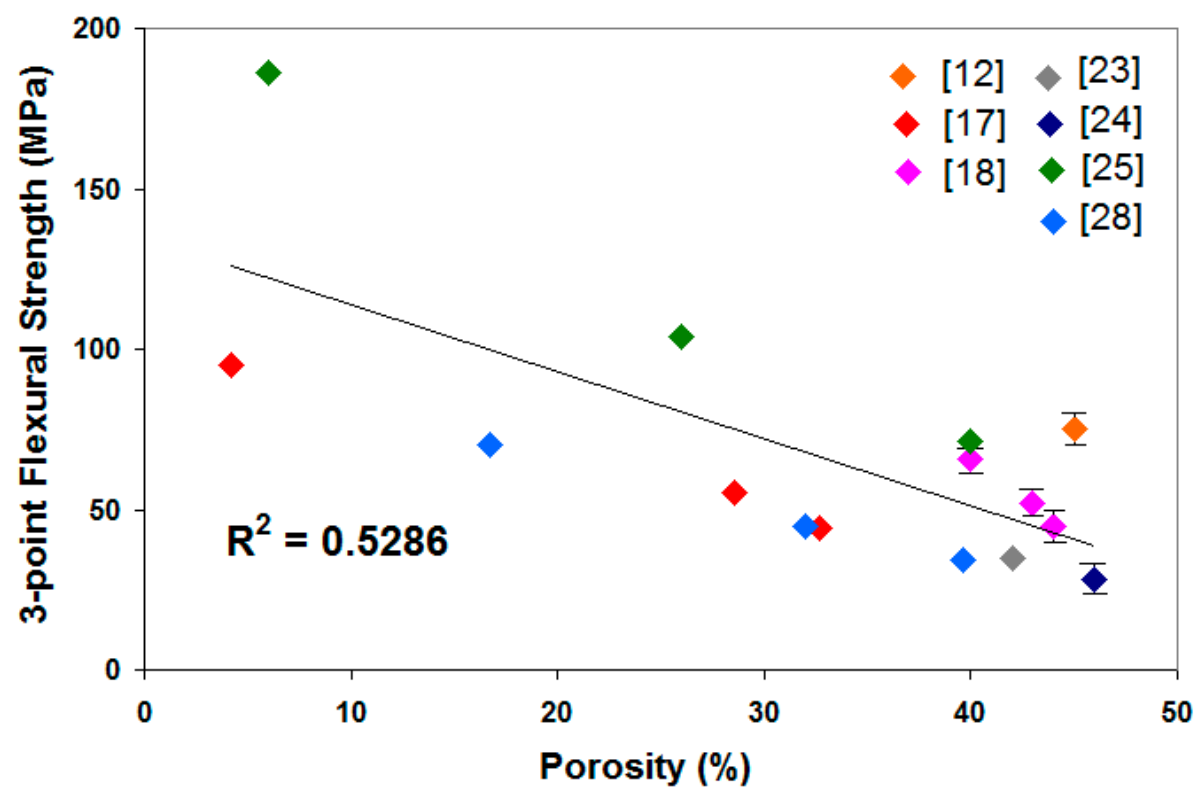

Figure 2. 3-point flexural strength correlation with porosity. 
Choo et al. [16] reported that mullite content can be maximized by adjusting the $\mathrm{Al}_{2} \mathrm{O}_{3} / \mathrm{SiO}_{2}$ weight ratio of precursor to 2.55 , which is the ratio of a stable stoichiometric $3: 2$ mullite $\left(3 \mathrm{Al}_{2} \mathrm{O}_{3} \cdot 2 \mathrm{SiO}_{2}\right.$, $71.8 \mathrm{wt} \% \mathrm{Al}_{2} \mathrm{O}_{3}$ ). The ratio adjusting methods reported by the literatures generally can be divided into two groups. The first group is the addition of aluminum source which is the most utilized method. The second group is the removal of silica or desilication. Although the methods in the two groups can increase the mullite content in the sample, the mechanical strengths of the resultant mullite are different. This can be seen by comparing the flexural strength of mullite that was produced by addition of aluminum source $[25,34]$ with mullite produced by desilication $[28,29]$ in Table 3 . The result showed that mullite produced by the addition of aluminum source has better flexural strength than that of desilication. Generally flexural strength is about 10 to 20 percent of the compressive strength, this means that flexural strength of the mullite reported in [29] is lower than the value reported in [25,34].

The capability of chemical additives such as $\mathrm{AlF}_{3}[12,19-21], \mathrm{V}_{2} \mathrm{O}_{5}$ [17,21], $\mathrm{MoO}_{3}$ [19,20], $\mathrm{MgO}$ [23], and $\mathrm{TiO}_{2}$ [24] to enhance the mechanical strengths of mullite ceramics has been demonstrated. For instance, the addition of $7 \mathrm{wt} \% \mathrm{AlF}_{3}$ enhanced the bending strength of porous mullite ceramics [12]. Similarly, the addition of $10 \mathrm{~mol} \% \mathrm{~V}_{2} \mathrm{O}_{5}$ also accelerated mullite formation, yielding homogeneous and relatively dense ceramics, leading to enhanced mechanical properties of the resultant ceramics [17]. Other method reported to enhance open porosity and strength of mullite porous membrane support was the use of a mixed addition of $\mathrm{AlF}_{3}$ and $\mathrm{MoO}_{3}[19,20]$. The use of small amounts of $\mathrm{MgO}(4 \mathrm{wt} \%)$ and $\mathrm{TiO}_{2}(6 \mathrm{wt} \%)$ was also shown to improve the strength of mullite ceramics [23,24].

Generally, the reported flexural strengths of mullite prepared from industrial wastes (28-186 MPa) are lower than that of mullite prepared from reagent grade chemical $(364 \mathrm{MPa})$, as reported by Mizuno [42]. Mechanical properties are strongly dependent on the microstructural parameters, such as grain size and shape, crystalline phase composition, relative volume of crystalline and amorphous phases, and porosity. Mullite ceramics prepared from industrial wastes are usually heterogeneous materials, with multiple phases and additional porosity (open and closed). These heterogeneities are related to the physicochemical and structural particularities of the initial powders, to the grain size repartition and shape as well as to the individual transformation and interactions of components during the sintering process [43]. Chemical additives that were used to serve various specific functions in the sintering process also played a significant role in ceramics mechanical properties. This resulted in different mechanical strength values been reported in the studies.

\section{Thermal Expansion}

Thermal expansion is an important factor that governs the durability of ceramics, especially refractories. The durability of ceramics can be reduced by failures such as spalling and thermal shock. These failures are closely related to the coefficient of thermal expansion (CTE) value of the ceramic. Materials with low CTE have good spalling resistance that minimizes the chance of cracking of refractories in service [44]. Similarly, thermal shock can be prevented by improving the robustness of a material against thermal shock by reducing the CTE value [45].

Mullite is a good refractory ceramic with excellent thermal shock resistance property owing to its low CTE value. This excellent property enables the material to be used for making kiln furniture, catalytic convertors, furnace tubes and heat shields. Table 4 compares the CTE value between the mullite ceramics produced from industrial wastes and from other sources. The results showed that the CTE values of mullite ceramics produced from the industrial wastes ranged from 5.6 to $6.1 \times 10^{-6}{ }^{\circ} \mathrm{C}^{-1}$. Their values were slightly higher than those of mullite ceramics produced from minerals, which range from 5.0 to $5.7 \times 10^{-6}{ }^{\circ} \mathrm{C}^{-1}$ [46-48], the CTE of commercial mullite of $5.5 \times 10^{-6}{ }^{\circ} \mathrm{C}^{-1}$ [49]. 
Table 4. Comparison of the coefficient of thermal expansion (CTE) value between the mullite ceramics produced from industrial wastes and from other sources.

\begin{tabular}{ccccc}
\hline Ref. & Raw Materials & Type of Raw Materials & $\begin{array}{c}\text { Ceramics } \\
\text { Product }\end{array}$ & CTE $\left(\times 10^{-6}{ }^{\circ} \mathbf{C}^{-1}\right) /$ Temperature Range \\
\hline$[5]$ & aluminum sludge + ceramic raw materials & Industrial wastes & mullite & $5.6 / 20-800^{\circ} \mathrm{C}$ \\
{$[16]$} & coal fly ash + Al dross & Industrial wastes & mullite & $5.8 / 30-1000{ }^{\circ} \mathrm{C}$ \\
{$[18]$} & coal fly ash + bauxite & Industrial wastes & porous mullite & $6.1 / 26-1000^{\circ} \mathrm{C}$ \\
{$[23]$} & coal fly ash + bauxite & Industrial wastes & mullite & $5.9 / 26-1550^{\circ} \mathrm{C}$ \\
{$[46]$} & drift sand + alumina & minerals & mullite & $5.5 / 30-900^{\circ} \mathrm{C}$ \\
{$[47]$} & alumina + silica + kaolin & minerals & porous mullite & $5.6 / 200-900^{\circ} \mathrm{C}$ \\
{$[48]$} & ball clay + alumina + kaolin & minerals & Mullite/alumina & $5.0-5.7 / 400-1200^{\circ} \mathrm{C}$ \\
{$[49]$} & commercial mullite (Duramul 325F) & Laboratory grade chemicals & Porous mullite & $5.5 / 30-1200^{\circ} \mathrm{C}$ \\
\hline
\end{tabular}

\section{Conclusions}

Driven by the need for low-cost and environmentally friendly alternatives, many research efforts have used a variety of industrial wastes as starting materials to produce mullite ceramics. The processing methods, sintering temperatures, and chemical additives have been reviewed. The traditional route processing method that involved mixing, pressing, and reaction sintering of the mullite precursor was the most commonly used method due to its simplicity and cost effectiveness. Although this method is able to produce porous mullite ceramics, the apparent porosities of the resultant mullite ceramic were reported to stay below $50 \%$. On the other hand, freeze casting was shown to be able to produce highly porous mullite ceramic, with an apparent porosity of $67 \%$, even at a very high sintering temperature of $1500{ }^{\circ} \mathrm{C}$. A review of the sintering temperatures and different chemical additives used in the production of mullite was carried out. It is desirable to use a sintering temperature of above $1500{ }^{\circ} \mathrm{C}$ for mullite production, due to the higher reaction rate between $\mathrm{Al}_{2} \mathrm{O}_{3}$ and $\mathrm{SiO}_{2}$ in the precursor. However, excessive silica content associated with impurities in the precursor could lead to the sample deformation or meltdown during high-temperature sintering. As for the chemical additives, $\mathrm{CaF}_{2}$, $\mathrm{H}_{3} \mathrm{BO}_{3}, \mathrm{Na}_{2} \mathrm{SO}_{4}, \mathrm{TiO}_{2}, \mathrm{AlF}_{3}$, and $\mathrm{MoO}_{3}$ have been reported as an effective aid to lower sintering temperature while $\mathrm{V}_{2} \mathrm{O}_{5}, \mathrm{Y}_{2} \mathrm{O}_{3}$-doped $\mathrm{ZrO}_{2}$ and $3 \mathrm{Y}$-PSZ can be used to promote densification for mullite ceramics. Doping with chemical additives such as $\mathrm{AlF}_{3}, \mathrm{Na}_{2} \mathrm{SO}_{4}, \mathrm{NaH}_{2} \mathrm{PO}_{4} \cdot 2 \mathrm{H}_{2} \mathrm{O}, \mathrm{V}_{2} \mathrm{O}_{5}$, and $\mathrm{MgO}$ assisted anisotropic growth of the mullite whiskers, which subsequently enhanced the physical strength and toughness of the mullite ceramics.

As for the physical properties of the resultant mullite ceramics, the reported flexural strengths of mullite prepared from industrial wastes $(28-186 \mathrm{MPa})$ is lower than the mullite prepared from reagent grade chemical (364 MPa). The CTE values of mullite ceramics produced from industrial wastes, which ranged from 5.6 to $6.1 \times 10^{-6}{ }^{\circ} \mathrm{C}^{-1}$, were slightly higher than those reported for mullite ceramics produced from minerals, which ranged from 5.0 to $5.7 \times 10^{-6}{ }^{\circ} \mathrm{C}^{-1}$, as well as to that of commercial mullite, which is $5.5 \times 10^{-6}{ }^{\circ} \mathrm{C}^{-1}$. Finally, the analysis in this review could serve as a basis guide to develop mullite ceramics from industrial wastes for both technical and economic purposes.

Author Contributions: Conceptualization, T.F.C.; compiling and analysis, T.F.C.; writing-original draft preparation, T.F.C.; writing-review and editing, K.Y.K., M.A.M.S., K.A.M.; supervision, K.Y.K, M.A.M.S., K.A.M.

Funding: This research received no external funding.

Conflicts of Interest: The authors declare no conflict of interest.

\section{References}

1. Schneider, H.; Komarneni, S. Mullite; Wiley VCH: Weinheim, Germany, 2005; p. 241.

2. Bowen, N.L.; Greig, J.W. The system: $\mathrm{Al}_{2} \mathrm{O}_{3} \cdot \mathrm{SiO}_{2}$. J. Am. Ceram. Soc. 1924, 7, 238-254. [CrossRef]

3. Ismail, M.G.M.U.; Nakai, Z.; Minegishi, K. Synthesis of mullite powder and its characteristics. Int. J. High Technol. Ceram. 1986, 2, 123-134. [CrossRef]

4. Romero, A.R.; Elsayed, H.; Bernardo, E. Highly porous mullite ceramics from engineered alkali activated suspensions. J. Am. Ceram. Soc. 2018, 101, 1036-1041. [CrossRef] 
5. Ribeiro, M.J.; Labrincha, J.A. Properties of sintered mullite and cordierite pressed bodies manufactured using Al-rich anodising sludge. Ceram. Int. 2008, 34, 593-597. [CrossRef]

6. Ribeiro, M.J.; Tulyagavov, D.U.; Ferreira, J.M.; Labrincha, J.A. High-temperature mullite dissolution in ceramic bodies derived from Al-rich sludge. J. Eur. Ceram. Soc. 2005, 25, 703-710. [CrossRef]

7. Francis, A.; Vilminot, S. Crystallisation kinetics of mullite glass-ceramics obtained from alumina-Silica wastes. Int. J. Sustain. Eng. 2013, 6, 74-81. [CrossRef]

8. Bocardo, J.C.E.; Torres, J.T. Development of mullite/zirconia composites from a mixture of aluminum dross and zircon. Ceram. Int. 2009, 35, 921-924.

9. Suriyanarayanan, N.; Kannannithin, K.V.; Bernardo, E. Mullite glass ceramic production from coal ash and alumina by high-temperature plasma. J. Non-Oxide Glasses 2009, 1, 247-260.

10. Jung, J.S.; Park, H.C. Mullite ceramics derived from coal fly ash. J. Mater. Sci. Lett. 2001, 20, 1089-1091. [CrossRef]

11. Yang, T.Y.; Ji, H.B.; Yoon, S.Y.; Kim, B.K.; Park, H.C. Porous mullite composite with controlled pore structure processed using a freeze casting of TBA-based coal fly ash slurries. Resour. Conserv. Recycl. 2010, 54, 816-820. [CrossRef]

12. Li, S.; Du, H.; Guo, A.; Xu, H.; Yang, D. Preparation of self-reinforcement of porous mullite ceramics through in situ synthesis of mullite whisker in flyash body. Ceram. Int. 2012, 38, 1027-1032. [CrossRef]

13. Dong, Y.; Diwu, J.; Feng, X.; Feng, X.; Liu, X.; Meng, G. Phase evolution and sintering characteristics of porous mullite ceramics produced from the flyash- $\mathrm{Al}(\mathrm{OH})_{3}$ coating powders. J. Alloys Compd. 2008, 460, 651-657. [CrossRef]

14. Tan, H. Preparation of mullite whiskers from coal fly ash using sodium sulfate flux. Int. J. Miner. Process. 2011, 100, 188-189. [CrossRef]

15. Park, Y.M.; Yang, T.Y.; Yoon, S.Y.; Stevens, R.; Park, H.C. Mullite whiskers derived from coal fly ash. Mater. Sci. Eng. A 2007, 455, 518-522. [CrossRef]

16. Choo, T.F.; Salleh, M.A.M.; Kok, K.Y.; Matori, K.A. Mineralogy and thermal expansion study of mullite-based ceramics synthesized from coal fly ash and aluminum dross industrial wastes. Ceram. Int. 2019, 45, 884-890.

17. Li, J.; Ma, H.; Huang, W. Effect of $\mathrm{V}_{2} \mathrm{O}_{5}$ on the properties of mullite ceramics synthesized from high-aluminum fly ash and bauxite. J. Hazard. Mater. 2009, 166, 1535-1539. [CrossRef] [PubMed]

18. Dong, Y.; Zhou, J.; Lin, B.; Wang, Y.; Wang, S.; Miao, L.; Lang, Y.; Liu, X.; Meng, G. Reaction-sintered porous mineral-based mullite ceramic membrane supports made from recycled materials. J. Hazard. Mater. 2009, 172, 180-186. [CrossRef] [PubMed]

19. Zhu, L.; Dong, Y.; Hampshire, S.; Cerneaux, S.; Winnubst, L. Waste-to-resource preparation of a porous ceramic membrane support featuring elongated mullite whiskers with enhanced porosity and permeance. J. Eur. Ceram. Soc. 2015, 35, 711-721. [CrossRef]

20. Zhu, L.; Dong, Y.; Li, L.; Liu, J.; You, S. Fabrication of mullite-whisker-structured porous. RSC Adv. 2015, 5, 11163-11174. [CrossRef]

21. Cao, J.; Dong, X.; Li, L.; Dong, Y.; Hampshire, S. Recycling of waste fly ash for production of porous mullite ceramic membrane supports with increased porosity. J. Eur. Ceram. Soc. 2014, 34, 3181-3194. [CrossRef]

22. Yugeswaran, S.; Ananthapadmanabhan, P.V.; Kobayashi, A.; Lusvarghi, L. Transferred arc plasma processed mullite from coal ash and bauxite. Ceram. Int. 2011, 37, 3437-3444. [CrossRef]

23. Dong, Y.; Hampshire, S.; Zhou, J.; Ji, Z.; Wang, J.; Meng, G. Sintering and characterization of flyash-based mullite with MgO addition. J. Eur. Ceram. Soc. 2011, 31, 687-695. [CrossRef]

24. Dong, Y.; Hampshire, S.; Zhou, J.; Lin, B.; Ji, Z.; Zhang, X.; Meng, G. Recycling of fly ash for preparing porous mullite membrane supports with titania addition. J. Hazard. Mater. 2010, 180, 173-180. [CrossRef] [PubMed]

25. Dong, Y.; Feng, X.; Feng, X.; Ding, Y.; Liu, X.; Meng, G. Preparation of low-cost mullite ceramics from natural bauxite and industrial waste fly ash. J. Alloys Compd. 2008, 460, 599-606. [CrossRef]

26. Mondal, A.; Maitra, S.; Chandra, S.; Mitra, N.K. Alumina-Mullite Composites through Interaction of Bauxite and Fly Ash. Trans. Indian Ceram. Soc. 2008, 67, 81-85. [CrossRef]

27. Kusnierova, M.; Prascakova, M.; Matysek, D.; Cablík, V. Mullitization of black coal fly ashes. Acta Montan. Slovaca 2011, 16, 192-196.

28. Guo, A.; Liu, J.; Xu, R.; Xu, H.; Wang, C. Preparation of mullite from desilication-flyash. Fuel 2010, 89, 3630-3636. [CrossRef] 
29. Lin, B.; Li, S.; Hou, X.; Li, H. Preparation of high performance mullite ceramics from high aluminum fly ash by an effective method. J. Alloys Compd. 2015, 623, 359-361. [CrossRef]

30. Catarino, L.; Sousa, J.; Martins, I.M.; Vieira, M.T.; Oliveira, M.M. Ceramic products obtained from rock wastes. J. Mater. Process. Technol. 2003, 144, 843-845. [CrossRef]

31. Souza, L.P.D.F.; Mansur, H.S. Production and characterization of ceramic pieces obtained by slip casting using powder wastes. J. Mater. Process. Technol. 2004, 145, 14-20. [CrossRef]

32. Oliveira, F.A.C.; Livramento, V.; Delmas, F. Novel mullite-based ceramics manufactured from inorganic wastes I. Densification behaviour. J. Mater. Process. Technol. 2007, 6, 101-108.

33. Martins, I.M.; Sousa, J.B.; Catarino, L.; Vieira, M.T.; Oliveira, M. The Formation of Mullite from Rock Wastes Containing Alumina and Silica. In Key Engineering Materials; Trans Tech Publications: Zurich, Switzerland, 2002; Volume 230, pp. 380-383.

34. Martins, I.M.; Vieira, S.; Livramento, V.; Sousa, J.; Delmas, F.; Oliveira, M.M.; Viera, M.T. Manufacture of Ceramic Products Using Inertized Aluminum Sludges. In Materials Science Forum; Trans Tech Publications: Zurich, Switzerland, 2004; Volume 456, pp. 822-826.

35. Vieira, M.T.; Catarino, L.; Oliveira, M.; Sousa, J.; Torralba, J.M.; Cambronero, L.E.G.; Gonzalez-Mesones, F.L.; Victoria, A. Optimization of the sintering process of raw material wastes. J. Mater. Process. Technol. 1999, 93, 97-101. [CrossRef]

36. Brasileiro, M.I.; Rodrigues, A.W.B.; Menezes, R.R.; Neves, G.A.; Santana, L.N.L. The Kaolin Residue and Its Use for Production of Mullite Bodies. In Sustainable Development-Energy, Engineering and Technologies-Manufacturing and Environment; Ghenai, C., Ed.; InTech: Rijeka, Croatia, 2012; pp. 117-142.

37. Choo, T.F.; Murshidi, J.A.; Saidin, N.U.; Paulus, W.; Abdullah, Y. Production of Mullite Ceramic Bodies from Kaolin Processing Waste and Aluminum Hydroxide. In Materials Science Forum; Trans Tech Publications: Zurich, Switzerland, 2017; Volume 888, pp. 81-85.

38. Sembiring, S.; Simanjuntak, W.; Manurung, P.; Asmi, D.; Low, I.M. Synthesis and characterisation of gel-derived mullite precursors from rice husk silica. Ceram. Int. 2014, 40, 7067-7072. [CrossRef]

39. Serra, M.F.; Conconi, M.S.; Gauna, M.R.; Suárez, G.; Aglietti, E.F.; Rendtorff, N.M. Mullite (3Al2O3·2SiO2) ceramics obtained by reaction sintering of rice husk ash and alumina, phase evolution, sintering and microstructure. J. Asian Ceram. Soc. 2016, 4, 61-67. [CrossRef]

40. Aripin, H.; Mitsudo, S.; Prima, E.S.; Sudiana, I.N.; Kikuchi, H.; Sano, S.; Sabchevski, S. Crystalline mullite formation from mixtures of alumina and a novel material-Silica xerogel converted from sago waste ash. Ceram. Int. 2015, 41, 6488-6497. [CrossRef]

41. Khattab, R.M.; EL-Rafei, A.M.; Zawrah, M.F. In situ formation of sintered cordierite-mullite nano-micro composites by utilizing of waste silica fume. Mater. Res. Bull. 2012, 47, 2662-2667. [CrossRef]

42. Mizuno, M. Microstructure, Microchemistry, and Flexural Strength of Mullite Ceramics. J. Am. Ceram. Soc. 1991, 74, 3017-3022. [CrossRef]

43. Sadik, C.; Amrani, I.E.; Albizane, A. Recent advances in silica-alumina refractory: A review. J. Asian Ceram. Soc. 2014, 2, 83-96. [CrossRef]

44. Harbison, W. Handbook of Refractory Practice; Harbison-walker refractories Co.: Mount Union, PA, USA, 2005.

45. Xin, Q. Diesel Engine System Design; Woodhead Publishing in Mechanical Engineering: Cambridge, UK, 2011.

46. Wang, W.; Shi, Z.; Wang, Z.; Wang, S. Phase transformation and properties of high-quality mullite ceramics synthesized using desert drift sands as raw materials. Mater. Lett. 2018, 221, 271-274. [CrossRef]

47. Mahnicka-Goremikina, L.; Svinka, R.; Svinka, V. Influence of $\mathrm{ZrO}_{2}$ and $\mathrm{WO}_{3}$ doping additives on the thermal properties of porous mullite ceramics. Ceram. Int. 2018, 44, 16873-16879. [CrossRef]

48. Peretz, I.; Bradt, R.C. Linear thermal expansion coefficients of mullite-matrix aluminosilicate refractory bodies. J. Am. Ceram. Soc. 1983, 66, 823-829. [CrossRef]

49. Feng, F.; Jang, B.; Park, J.Y.; Lee, K.S. Effect of $\mathrm{Yb}_{2} \mathrm{SiO}_{5}$ addition on the physical and mechanical properties of sintered mullite ceramic as an environmental barrier coating material. Ceram. Int. 2016, 42, 15203-15208. [CrossRef]

(C) 2019 by the authors. Licensee MDPI, Basel, Switzerland. This article is an open access article distributed under the terms and conditions of the Creative Commons Attribution (CC BY) license (http://creativecommons.org/licenses/by/4.0/). 